\title{
Cell Adhesion Molecule 2
}

National Cancer Institute

\section{Source}

National Cancer Institute. Cell Adhesion Molecule 2. NCI Thesaurus. Code C95846.

Cell adhesion molecule 2 (435 aa, $\sim 48 \mathrm{kDa}$ ) is encoded by the human CADM2 gene. This protein is involved in the mediation of both adherens junction structure and cell adhesion. 